\title{
ANALISIS REALISASI PENDAPATAN PERUSAHAAN DAERAH (PD) PASAR BANYUASRI KABUPATEN BULELENG TAHUN 2015-2017 SERTA FAKTOR - FAKTOR YANG MEMPENGARUHINYA
}

\author{
Ni Putu Noviyantini, Luh Putu Novita Wahyuni, \\ Ni Luh Putu Ika Baktyarina, Ni Luh Asri
}

Jurusan Akuntansi, Universitas Pendidikan Ganesha, Singaraja, Bali, Indonesia

\begin{abstract}
Abstrak
Penelitian ini bertujuan untuk mengetahui bagaimana realisasi pendapatan Perusahaan Daerah (PD) Pasar Banyuasri Kabupaten Buleleng Tahun 2015 - 2017 , apa saja faktor - faktor yang mempengaruhi penurunan realisasi pendapatan Perusahaan Daerah (PD) Pasar Banyuasri Kabupaten Buleleng Tahun 2015 - 2017 , bagaimana upaya dalam meningkatkan realisasi pendapatan Perusahaan Daerah (PD) Pasar Banyuasri Kabupaten Buleleng. Dalam penelitian menggunakan metode kualitatif dan menggunakan teknik pengumpulan data wawancara. Dari hasil peenelitian Pada tahun 2015 realisasi pendapatan yang dapat dicapai Perusahaan Daerah (PD) Pasar Banyuasri Kabupaten Buleleng sebesar Rp 1.840.038.765. Sedangkan di tahun 2016 realisasi pendapatan yang dapat dicapai sebesar $\mathrm{Rp}$ 1.838.629.007. Dari data realisasi pendapatan tersebut dapat dilihat bahwa terjadi penurunan pendapatan sebesar Rp 1.409.758
\end{abstract}

Kata kunci: Realisasi, Pendapatan, Pasar

\begin{abstract}
This study aims to find out how the realization of Regional Company Revenue (PD) of Banyuasri Market in Buleleng Regency in 2015 - 2017, what are the factors that influence the decline in revenue of Regional Enterprises (PD) of Banyuasri Market in Buleleng Regency in 2015 - 2017, how to improve efforts revenue realization of Regional Company (PD) Banyuasri Market in Buleleng Regency. In research using qualitative methods and using interview data collection techniques. From the results of research In 2015 the realization of revenue that can be achieved by the Regional Company (PD) of the Banyuasri Market in Buleleng Regency amounted to Rp 1,840,038,765. Whereas in 2016 the realization of revenue that could be achieved was $R p$ 1,838,629,007. From the revenue realization data it can be seen that there was a decrease in income of $R p 1,409,758$
\end{abstract}

Keywords: Realization; income; Market

\section{Pendahuluan}

Perusahaan Daerah (PD) Pasar Kabupaten Buleleng adalah bagian dari Pemerintah Daerah, sampai saat ini mengelola beberapa unit pasar milik Pemerintah Kabupaten berdasarkan SK Bupati No.370 Tahun 2004 Tentang Penyerahan Aset. Perusahaan Daerah (PD) Pasar Banyuasri merupakan salah satu unit Perusahaan Daerah (PD) Kabupaten Buleleng yang mengelola aset pasar.Pasar Banyuasri merupakan salah satu pasar besar di Kabupaten Buleleng.

Perusahaan Daerah (PD) Pasar Banyuasri setiap tahunnya menerima pendapatan dari berbagai sumber diantaranya seperti cukai harian, sewa tanah berjalan, sewa tanah tunggakan, denda, listrik, jasa, setoran WC, dan setoran parkir. Meskipun Pasar Banyuasri merupakan salah satu Pasar terbesar di Kabupaten Buleleng, namun pendapatan yang diperoleh Perusahaan Daerah (PD) Pasar Banyuasri Kabupaten Buleleng tidak serta merta mengalami peningkatan setiap tahunnya.Hal ini dibuktikan dari Laporan Realisasi Pendapatan Retribusi Pasar selama tiga tahun dimulai dari tahun 2015 hingga tahun 2017.

Pada tahun 2015 realisasi pendapatan yang dapat dicapai Perusahaan Daerah (PD) Pasar Banyuasri Kabupaten Buleleng sebesar Rp 1.840.038.765.Sedangkan di tahun 2016 realisasi pendapatan yang dapat dicapai sebesar $\mathrm{Rp}$ 1.838.629.007. Dari data realisasi pendapatan tersebut dapat dilihat bahwa terjadi penurunan pendapatan sebesar $\mathrm{Rp}$ 1.409.758.

Perbandingan selanjutnya, di tahun 2016 realisasi pendapatan yang dapat dicapai sebesar Rp 1.838.629.007.Sedangkan di tahun 2017 realisasi pendapatan yang dapat 
dicapai sebesar $\mathrm{Rp}$ 1.698.419.690. Dari data realisasi pendapatan tersebut dapat dilihat bahwa terjadi penurunan pendapatan sebesar Rp 140.209.317.

Berdasarkan permasalahan di atas, maka penulis tertarik untuk melakukan penelitian terkait faktor-faktor yang mempengaruhi penurunan pendapatan yang dicapai oleh Perusahaan Daerah (PD) Pasar Banyuasri Kabupaten Buleleng serta upaya yang dapat ditawarkan untuk meningkatkan pendapatan yang diperoleh setiap tahunnya dengan judul penelitian "Analisis Realisasi Pendapatan Perusahaan Daerah (PD) Pasar Banyuasri Kabupaten Buleleng tahun 2015-2017 serta Faktor - Faktor yang Mempengaruhinya"

Berdasarkan permasalahan di atas dapat diuraikan rumusan masalah sebagai berikut: bagaimana realisasi pendapatan Perusahaan Daerah (PD) Pasar Banyuasri Kabupaten Buleleng Tahun 2015 - 2017 , apa saja faktor - faktor yang mempengaruhi penurunan realisasi pendapatan Perusahaan Daerah (PD) Pasar Banyuasri Kabupaten Buleleng Tahun 2015 - 2017 , bagaimana upaya dalam meningkatkan realisasi pendapatan Perusahaan Daerah (PD) Pasar Banyuasri Kabupaten Buleleng .

\section{Metode}

\section{Tempat dan WaktuPenelitian}

Penelitian ini dilakukan di Perusahaan Daerah Pasar Banyuasri, Kecamatan Buleleng, Kabupaten Buleleng, Bali.Penelitian ini dilakukan pada tanggal 10 April 2018.

\section{Jenis dan Sumber Data}

Jenis data yang kami gunakan dlam penyususnan penelitian ini menggunkan data primer yaitu data yang kami peroleh berasal dari responden melalui wawancara penelitian dengan narasuber, yakni orang yang menjawab pertanyaan penelitian dengan tertulis dan lisan.Sehingga menghasilkan data yang kami harapkan.Penelitian ini juga menggunakan Data Kuantitatif yaitu data yang mencakup data numerik.

\section{Teknik Pengumpulan Data}

Untuk mengumpulkan data dalam karya tulis ini, dilakukan dengan wawancara dan observasi.

a. Observasi

Observasi yang dilakukan bertempat di Kantor Perusahaa Daerah (PD) Pasar Banyuasri dan di lingkungan pasar Banyuasri Kabupaten Buleleng.

b. Wawancara

Suatu percakapan yang diarahkan pada suatu masalah tertentu. Hal ini merupakan proses tanya jawab lisan dimana dua orang atau lebih berhadapan secara fisik. Wawancara dalam penelitian ini dilakukan dengan pegawai Perusahaan Daerah Pasar Banyuasri.

\section{Populasi dan sampel}

a. Populasi

Populasi merupakan kumpulan orang, benda atau hal lain yang menjadi subjek penelitian (Riduwan, 2006:49). Sebagai populasi dalam penelitian ini adalah data pendapatan Perushaan Daerah Pasar Banyuasri.

b. Sampel

Sampel adalah bagian dari populasi yang diteliti dalam suatu penelitian (Riduwan 2006:49).Sebagai sampel dalam penelitian ini adalah data pendapatan Perusahaan Daerah Pasar Banyuasri dari tahun 2015 sampai tahun 2017.

\section{Hasil dan Pembahasan}

\section{Realisasi Pendapatan Perusahaan Daerah (PD) Pasar Banyuasri Kabupaten Buleleng Tahun 2015 - 2017}

Realisasi Pendapatan Perusahaan Daerah (PD) Pasar Banyuasri Kabupaten Buleleng terdiri dari cukai harian, sewa tanah, listrik, jasa, setoran WC, serta parkir. Pada tahun 2015 total penerimaan dari cukai harian adalah sebesar Rp 1.194.363.000. Sewa tanah sebesar Rp 392.317.765. Total penerimaan biaya listrik sebesar $\mathrm{Rp} \mathrm{67.329.000.} \mathrm{Total} \mathrm{penerimaan}$ setoran jasa sebesar Rp 2.554.000. Total penerimaan setoran WC sebesar Rp 55.628.000 serta total penerimaan setoran parkir sebesar Rp 127.847.000. Sehingga Pada tahun 2015 
realisasi pendapatan yang dapat dicapai Perusahaan Daerah (PD) Pasar Banyuasri Kabupaten Buleleng sebesar Rp 1.840.038.765.

Pada tahun 2016 total penerimaan dari cukai harian adalah sebesar $R p$ 1.191.912.000. Sewa tanah sebesar Rp 333.953.007. Total penerimaan biaya listrik sebesar Rp 67.426.000. Total penerimaan setoran jasa sebesar Rp 6.540.000. Total penerimaan setoran WC sebesar Rp 59.290.000 serta total penerimaan setoran parkir sebesar Rp 179.508.000. Sehingga Pada tahun 2016 realisasi pendapatan yang dapat dicapai Perusahaan Daerah (PD) Pasar Banyuasri Kabupaten Buleleng sebesar Rp1.838.629.007.

Pada tahun 2017 total penerimaan dari cukai harian adalah sebesar $R p$ 1.099.524.000. Sewa tanah sebesar Rp 285.576.690. Total penerimaan biaya listrik sebesar Rp 65.852.000. Total penerimaan setoran jasa sebesar Rp 2.870.000. Total penerimaan setoran WC sebesar Rp 62.170.000 serta total penerimaan setoran parkir sebesar Rp 182.427.000. Sehingga Pada tahun 2017 realisasi pendapatan yang dapat dicapai Perusahaan Daerah (PD) Pasar Banyuasri Kabupaten Buleleng sebesar Rp 1.698.419.690.

Berdasarkan analisis yang telah dilakukan dengan melihat perbandingan jumlah realisasi pendapatan dari tahun 2015 sampai 2017 diperoleh hasil sebagai berikut : Pada tahun 2015 realisasi pendapatan yang dapat dicapai Perusahaan Daerah (PD) Pasar Banyuasri Kabupaten Buleleng sebesar Rp 1.840.038.765. Sedangkan di tahun 2016 realisasi pendapatan yang dapat dicapai sebesar $\mathrm{Rp}$ 1.838.629.007. Dari data realisasi pendapatan tersebut dapat dilihat bahwa terjadi penurunan pendapatan sebesar Rp 1.409.758.

Perbandingan selanjutnya, di tahun 2016 realisasi pendapatan yang dapat dicapai sebesar Rp 1.838.629.007.Sedangkan di tahun 2017 realisasi pendapatan yang dapat dicapai sebesar $\mathrm{Rp}$ 1.698.419.690.Dari data realisasi pendapatan tersebut dapat dilihat bahwa terjadi penurunan pendapatan yang sangat drastic sebesar Rp 140.209.317.

\section{Faktor - faktor yang mempengaruhi Penurunan Realisasi Pendapatan Perusahaan Daerah (PD) Pasar Banyuasri Kabupaten Buleleng Tahun 2015 - 2017}

Berdasarkan hasil wawancara dengan staf PD Pasar Banyausri, factor penyebab menurunnya realisasi pendapatan perusahaan daerah pasar Banyuasri Kabupaten Buleleng dari tahun 2015 hingga tahun 2017 adalah mengalami penurunan. Data penurunan realisasi pendapatan dapat dilihat dari jumlah total pendapatan per tahunnya. Pada tahun 2015 realisasi pendapatan yang dapat dicapai oleh PD Pasar Banyuasri Kabupaten Buleleng sebesar Rp. 1.840.038.765, sedangkan realisasi pendapatan pada tahun 2016 yang dapat dicapai adalah sebesar Rp. 1.838.629.007, dan pada tahun 2017 adalah sebesar Rp. 1.698.419.690. Dari data yang diperoleh menunjukkan adanya penurunan pendapat dengan total pengunjung tahun 2015 sejumlah 255.694 pengunjung, tahun 2016 sejumlah 359.016 pengunjung, dan padatahun 2017 sejumlah 182.427 pengunjung.

Dari jumlah data pengunjung pada tahun 2016 hingga tahun 2017 mengalami penurunan, penurunan realisasi pendapatan terlihat pada data setoran parkir. Faktor yang mempengaruhi penurunan realisasi pendapatan pada Perusahaan Daerah (PD) Pasar Banyuasri Kabupaten Buleleng yaitu sebagai berikut :

1. Pada tarif parkir yaitu pemungutan parkir yang meningkat dimana pada tahun 2016 sebesar Rp.500 sedangkan pada tahun 2017 naik menjadi Rp.1000. Hal itu yang menjadi salah satu penyebab pengunjung pasar menjadi menurun.

2. Faktor selanjutnya adalah karena semakin banyaknya jumlah pasar yang ada sehingga tingkat persaingan juga semakin tinggi. Banyak

pasar-pasar yang ada di Buleleng terutama di Kota Singaraja, misalnya Pasar Anyar, Pasar Buleleng, Pasar Ten-Ten, Pasar Kebon dan masih banyak lagi.

3. Pada era digital saat ini, lapisan masyarakat sudah dimudahkan dalam segala hal. Salah satunya adalah berkaitan dengan penyediaan aplikasi bisnis makanan atau minuman. Seperti contohnya pada aplikasi GRAB atau GO-JEK, dengan aplikasi ini semua orang bisa memesan makanan ataupun minuman cepat saji dengan waktu yang singkat, dan harga yang dikeluarkan untuk membayar makanan ditambah jasa yang standar membuat kebanyakan orang lebih memilih gaya hidup yang praktis. 
Dengan begitu hingga saat ini, tidak banyak masyarakat yang masih ingin pergi ke pasar tradisional untuk membeli keperluan memasak.

\section{Upaya Dalam Meningkatkan Realisasi Pendapatan Perusahaan Daerah (PD) Pasar Banyuasri Kabupaten Buleleng}

Berdasarkan data pendapatan PD Pasar Banyuasri di lapangan dari tahun 2015-2017 upaya yang dapat dilakukan oleh pihak instansi Perusahaan Dagang (PD) Pasar Banyuasri untuk meningkatkan realisasi Pendapatan PD Pasar Banyuasri yaitu; (1) menentukan kebijakan terkait tindak lanjut bagi pedagang yang belum memenuhi kewajibannya secara tepat; (2) melaksanakan rapat evaluasi internal yang lebih intensif secara berkala untuk membahas masalah-masalah yang dihadapi serta langkah- langkah yang telah maupun yang akan dilakukan; serta (3) memberlakukan surat peringatan.

Surat peringatan ini berfungsi dalam pemungutan iuran sewa tanah atau tempat.Surat peringatan ini memiliki tiga tingkatan yaitu tingkat pertama, kedua dan ketiga. Pertama hanya sebatas surat yang dikeluarkan pihak PD Pasar dengan tanda tangan Kepala PD Pasar untuk segera melunasi tagihan sewa tempat, kedua berupa surat yang dikeluarkan pihak PD Pasar dengan tanda tangan Kepala PD Pasar dan teguran langsung kepada pedagang yang bersangkutan serta ketiga berupa pengambilan hak kembali.

Selain itu terdapat dua usaha peningkatan pendapatan yaitu intensifikasi dan ekstensifikasi. Peningkatan pendapatan PD Pasar Banyuasri secara intensifikasi dapat dilakukan dengan cara (a) menyusun atau memperbaiki aspek kelembagaan atau organisasi pengelolaan pendapatan, beserta perangkatnya sesuai dengan kebutuhan yang terus berkembang; (b) memperbaiki atau menyesuaikan aspek ketatalaksanaan, baik administrasi maupun operasional yang meliputi penyesuaian atau penyempurnaan administrasi pemungutan; (c) peningkatan pengawasan dan pengendalian yang meliputi pengawasan dan pengendalian yuridis, teknis, dan penatausahaan; (d) peningkatan sumber daya manusia pengelola pendapatan misalnya dengan mengikutsertakan aparaturnya dalam kursus keuangan daerah (KKD) serta program-program pendidikan dan pelatihan tentang keuangan daerah lainnya. Upaya intensifikasi pada PD Pasar Banyuasri sangat diperlukan.Dalam hal ini pelaksanaan kegiatan pengelolaan data terkait PD Pasar Banyuasri masih semi-modern. Dari hasil observasi lapangan, pada kantor PD Pasar Banyuasri tidak terdapat computer dan peralatan elektronik lainnya yang dapat mempermudah pengolahan data. Sehingga hal ini dapat meningkatkan kemungkinan human error dan kurang efektif dalam pengolahan data pendapatan PD Pasar Banyuasri.

Peningkatan secara ekstensifikasi, yaitu usaha-usaha yang dilakukan untuk menggali sumber pendapatan yang baru, namun dalam upaya ekstensifikasi ini tidak boleh bertentangan dengan kebijaksanaan pokok nasional, yaitu pemungutan yang dilaksanakan tidak semata-mata untuk menggali pendapatan daerah berupa sumber penerimaan yang memadai, tetapi juga pelaksanaan agar tidak memberatkan masyarakat baik dari para pedagang maupun pembeli di Pasar Banyuasri

\section{Simpulan dan Saran \\ Simpulan}

Berdasarkan analisis yang telah dilakukan dengan melihat perbandingan jumlah realisasi pendapatan dari tahun 2015 sampai 2017 diperoleh hasil sebagai berikut : Pada tahun 2015 realisasi pendapatan yang dapat dicapai Perusahaan Daerah (PD) Pasar Banyuasri Kabupaten Buleleng sebesar Rp 1.840.038.765. Sedangkan di tahun 2016 realisasi pendapatan yang dapat dicapai sebesar $\mathrm{Rp}$ 1.838.629.007. Dari data realisasi pendapatan tersebut dapat dilihat bahwa terjadi penurunan pendapatan sebesar $R p$ 1.409.758 .Penurunan realisasi pendapatan pada Perusahaan Daerah (PD) Pasar Banyuasri bisa terjadi karena beberapa factor.yaitu sebagai berikut :

1. Pada tarif parkir yaitu pemungutan parkir yang meningkat dimana pada tahun 2016 sebesar Rp.500 sedangkan pada tahun 2017 naik menjadi Rp.1000. Hal itu yang menjadi salah satu penyebab pengunjung pasar menjadi menurun. 
2. Faktor selanjutnya adalah karena semakin banyaknya jumlah pasar yang ada sehingga tingkat persaingan juga semakin tinggi. Banyak pasar-pasar yang ada di Buleleng terutama di Kota Singaraja, misalnya Pasar Anyar, Pasar Buleleng, Pasar Ten-Ten, Pasar Kebon dan masih banyak lagi.

3. Pada era digital saat ini, lapisan masyarakat sudah dimudahkan dalam segala hal. Salah satunya adalah berkaitan dengan penyediaan aplikasi bisnis makanan atau minuman.

Upaya yang dapat dilakukan oleh pihak instansi Perusahaan Dagang (PD) Pasar Banyuasri untuk meningkatkan realisasi Pendapatan PD Pasar Banyuasri yaitu; (1) menentukan kebijakan terkait tindak lanjut bagi pedagang yang belum memenuhi kewajibannya secara tepat; (2) melaksanakan rapat evaluasi internal yang lebih intensif secara berkala untuk membahas masalah-masalah yang dihadapi serta langkah-langkah yang telah maupun yang akan dilakukan; serta (3) memberlakukan surat peringatan.

\section{Saran}

Berdasarkan simpulan tersebut, maka dapat diajukan saran yaitu Kepada pihak pemerintah khususnya Perusahaan Daerah (PD) Pasar antara lain:

1). Melakukan sosialisasi kepada masyarakat khususnya pedagang tentang sumber pendapatan Perusahaan Daerah (PD) Pasar agar masyarakat khususnya pedagang mengetahui dan menyadari bahwa pungutan tersebut digunakan untuk kepentingan daerah dan masyarakat sendiri.

2). Memberikan sosialisasi mengenai manajemen pemasaran agar pedagang mendapatkan lebih banyak pelanggan sehingga pendapatan Perusahaan Daerah (PD) Pasar meningkat dari waktu ke waktu.

\section{Daftar Pustaka}

Anonim.2018.

Pendapatan https://sudutekonomi.blogspot.com/2017/11/pengertianpendapatan.html. Diakses pada tanggal 15 Juni 2018, pukul 20:22 WITA

Anonim. MAteri Realisasi. http://www.pengertianmenurutparaahli.net/pengertian-realisasi/.

Diakses pada tanggal 15 Juni 2018, pukul 20:37 WITA

Damang Averrofs. 2011. http://www.negarahukum.com/hukum/perusahaandaerah.html.

Diakses pada tanggal 15 Juni 2018, pukul 21:02 WITA 
Jurnal Ilmiah Akuntansi dan Humanika, Vol. 7 No. 3, Desember 2017

ISSN: 2599-2651 